\title{
Genetic diversity in two variants of Orobanche gracilis Sm. [var. gracilis and var. deludens (Beck) A. Pujadas] (Orobanchaceae) from different regions of Spain
}

\author{
Belén Román* \\ Área de Mejora y Biotecnología \\ Instituto de Investigación y Formación Agraria y Pesquera (IFAPA-CICE) \\ Junta de Andalucía \\ CIFA "Alameda del Obispo" \\ Apdo. 3092 \\ 14080 Córdoba, Spain \\ Tel: 34957016125 \\ Fax: 34957016043 \\ E-mail: belen.roman.ext@juntadeandalucia.es \\ Rosabell Hernández \\ Departamento de Ciencias y Recursos Agrícolas y Forestales \\ Escuela Técnica Superior de Ingenieros Agrónomos y de Montes (ETSIAM) \\ Campus de Rabanales, Ed. Celestino Mutis \\ Universidad de Córdoba \\ 14071 Córdoba, Spain \\ Antonio José Pujadas-Salvá \\ Departamento de Ciencias y Recursos Agrícolas y Forestales \\ Escuela Técnica Superior de Ingenieros Agrónomos y de Montes (ETSIAM) \\ Campus de Rabanales, Ed. Celestino Mutis \\ Universidad de Córdoba \\ 14071 Córdoba, Spain \\ José Ignacio Cubero \\ Departamento de Genética \\ Escuela Técnica Superior de Ingenieros Agrónomos y de Montes (ETSIAM) \\ Campus de Rabanales, Ed. Gregor Mendel \\ Universidad de Córdoba \\ 14071 Córdoba, Spain \\ Diego Rubiales \\ Instituto de Agricultura Sostenible \\ Consejo Superior de Investigaciones Científicas (CSIC) \\ Apdo. 4084, 14080 Córdoba, Spain \\ Zlatko Satovic \\ Department of Seed Science and Technology \\ Faculty of Agriculture \\ University of Zagreb \\ Svetosimunska 25 \\ 10000 Zagreb, Croatia
}

Financial support: The work has been carried out at CIFA "Alameda del Obispo" (IFAFA-Área de Mejora y Biotecnología) and was supported by the INIA RTA04-067 project.

Keywords: AMOVA, molecular markers, Orobanche gracilis, parasitic plants, population genetics.

Abbreviations: $\quad$ AMOVA: Analysis of molecular variance

PCoA: Principal co-ordinate analysis

The pattern of genetic variation among populations of Southern Spain growing on different hosts was analysed two Orobanche gracilis Sm. taxa (var. gracilis and var. deludens (Beck) A. Pujadas) from Northern and

using RAPD markers. The diversity analysis within populations revealed a higher level of diversity in the

\footnotetext{
*Corresponding author
} 
populations from the North when compared to the Southern ones. The results of principal co-ordinate analysis (PCoA) based on Dice distances among samples clearly established the separation of samples according to the taxonomical variety and the geographical origin of each population. The Southern populations of both var. gracilis and var. deludens were more differentiated among them than those of var. gracilis from the North. The analysis of molecular variance (AMOVA) indicated that the lowest level of population differentiation was found in $O$. gracilis var. gracilis from the North, whereas in the case of $\boldsymbol{O}$. gracilis var. deludens from the South most of the genetic diversity was attributable to differences among populations. Possible explanations for the distribution of variation in these populations are discussed.

Orobanche species are plants adapted to a parasitic mode of life. Most of the species within Orobanche genus are found in the natural vegetation (Pujadas-Salvà, 2002) and do not, or only occasionally, occur on crop species. Nevertheless some of them have abandoned their natural hosts and became very noxious parasitic weeds, causing major crop losses. In this sense, $O$. crenata Forsk. causes huge damage to legume crops (faba bean, lentil, pea and common vetch); $O$. cumana Wallr. threatens sunflower; O. minor $\mathrm{Sm}$. infects clover; $O$. ramosa attacks potato, tobacco, tomato and hemp; and species such as $O$. foetida Poir. that traditionally has only been described on wilds, has been reported recently on crops such as chickpea and faba bean in Tunisia (Kharrat et al. 1992) and vetch in Morocco (Rubiales et al. 2005).

Although the economic importance has focused most of the research in this group mainly on physiological and applied issues, there are also many other aspects of both theoretical and practical interest that should be considered. In this sense, the study of natural $O$. populations can help us to understand gene pool dynamics, population size structure and geographical distribution, environmental adaptation and centres of origin. The parasitism has led to a simplification in the morphology of the genus (no leaves and only false roots) and therefore to a reduction in features used to distinguish species. Morphological traits are, therefore, of limited use to diversity studies due to its variation with environmental changes and estimation errors, and the reduced number of characteristic features available. In this context, the stability and the power of nucleic acid markers provides a clear advantage that has been exploited in different population studies of the genus, mainly considering species growing on crops of economical relevance such as $O$. cumana on sunflower (Gagne et al. 1998), O. crenata on legumes (Román et al. 2001; Román et al. 2002), or $O$. minor on clover (Westwood and Fagg, 2004).

In comparison with allozymes and microsatellites, RAPD markers present some limitations such as marker allele dominance and sometimes low reproducibility.
Nevertheless, the major advantage of RAPD analysis out weight its disadvantage since it can potentially provide a much higher number of marker loci and higher levels of polymorphism than allozymes and costs much less being faster and easier to perform that microsatellite analysis because no prior DNA sequence information for the target species is required. Under controlled reaction conditions, reproducible and interpretable RAPD banding patterns can be obtained.

Molecular data on the interaction between parasitic plants and their native species which have been growing together for thousands of years are of great interest, not only to determine evolution patterns but also because these host species might have evolved ways of avoiding parasitism along evolution. It is not known how parasitic plants, which once occurred in the natural vegetation and apparently did not have a devastating effect on their host plant, escapes their "natural" environment and became harmful in crops. Some of these weedy species are still natives through most of their ranges.

O. gracilis $\mathrm{Sm}$. grows on a wide range of wild Leguminosae scrubs hosts such as Adenocarpus hispanicus, Anthyllis cytisoides L., Astragalus granatensis Lam., Coronilla juncea L., Dorycnium pentaphyllum Scop., Erinacea anthyllis Link, Genista cinerea (Vill.) DC., G. falcata Brot., G. florida L., G. hispanica L., G. scorpius (L.) DC., G. versicolor Boiss., Retama sphaerocarpa (L.) Boiss., Ulex baeticus Boiss., U. canescens Lange, $U$. parviflorus Pourr. (cf. Pujadas-Salvà, 2002). O. gracilis species can be found in the Center and South of Europe and Northwest of Africa, growing widely distributed almost all over the Iberian Peninsula. Although the morphological features of $O$. gracilis are very variable, the species are easily distinguishable attending to the colour of the corolla: (intense red in the inside part and dark yellow in the outside surface) and its yellow stigma. In the Iberian peninsula, it is possible to distinguish between two variants of this species: $O$. gracilis Sm. var. gracilis and $O$. gracilis var. deludens (Beck) A. Pujadas (= O. austrohispanica Foley) (cf. Pujadas-Salvà and Plaza-Arregui, 2004). Although both variants present different morphologic traits that differentiate them, this is not always easy and they have often been confused due to the intrinsic variability among specimens from the same population and no clear-cut geographical separation between both taxa. Moreover, $O$. gracilis is a rare plant, not very abundant and with short number of samples per population which are difficult to locate, since they can easily disappear with high environmental temperatures, avoiding the collection of the proper material to be used in population diversity studies.

The aim of our present work is to study the genetic variation of these two varieties (var. gracilis and var. deludens) in order to (1) determine the genetic differences between them, (2) infer the inter and intra-population variability of both variants and (3) to determine the 


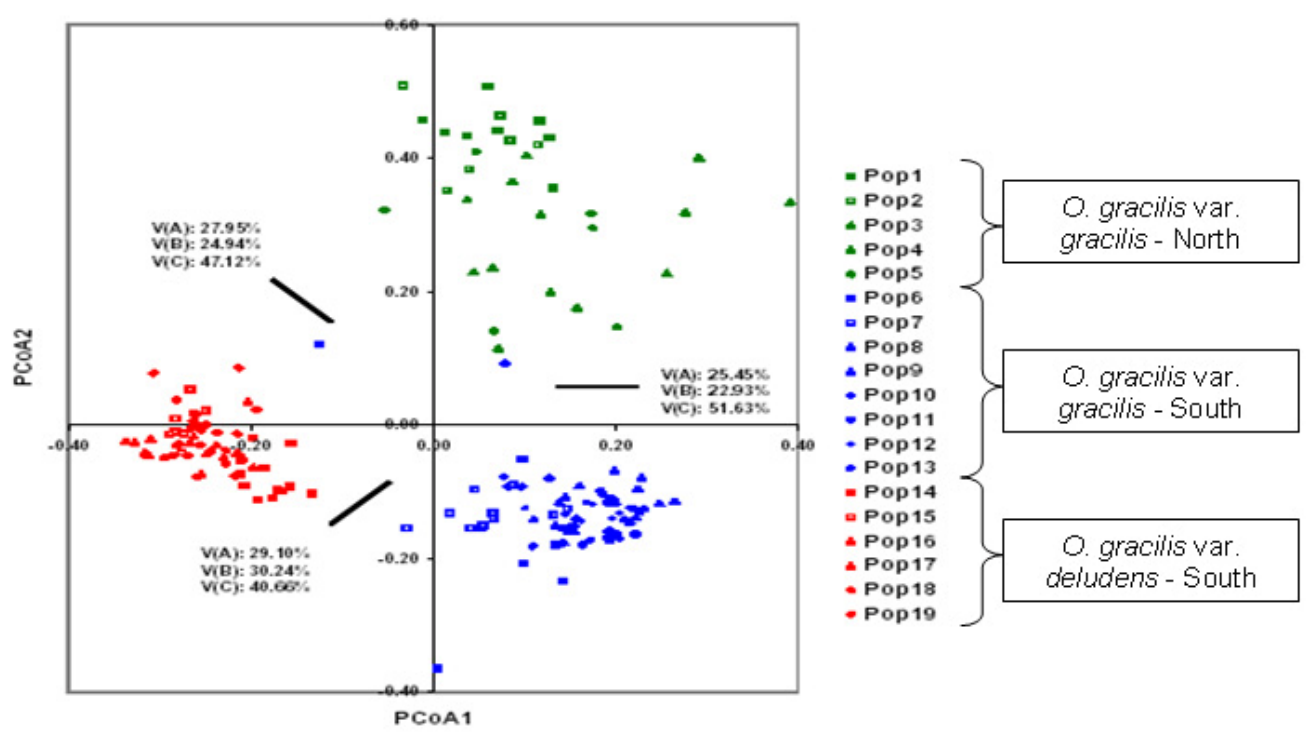

Figure 1. Principal coordinate analysis of the Dice's distance matrix (space defined by the first two coordinates). The pairwise partition of variation obtained with the AMOVA analysis is also shown.

geographical influence on genetic diversity in distant populations of $O$. gracilis var. gracilis.

\section{MATERIALS AND METHODS}

\section{Plant material}

A total of 166 specimens from 19 O. gracilis populations of two $O$. gracilis taxa (var. gracilis and var. deludens) were collected on different hosts over distinct regions of Spain. The number of Orobanche plants per populations analysed varied depending on the availability of specimens in each case. In Table 1 the number of each population, region, number of herbarium catalogue, host, collection site and number of samples analysed per population are shown. As presented in this table, three different groups can be established considering the variety and region of collection (North and South of the Iberian Peninsula): O. gracilis var. gracilis from the North, O. gracilis var. gracilis from the South and $O$. gracilis var. deludens from the South.

\section{Methods}

RAPD analysis. Orobanche floral buds were used for DNA extraction using the method used by Román et al. (2001). For RAPD analysis, approximately 20 ng of genomic DNA was used as a template in a $25 \mu \mathrm{l}$ volume per PCR reaction. Mixture composition and reaction conditions were as described by Román et al. (2001). Products were amplified in a Termocycler PE Applied Biosystems GeneAmp 9700.

A total of 15 primers of 10 bases length were analysed (OPA08, OPB03, OPB11, OPC18, OPD01, OPE08, OPF11, OPI19, OPJ01, OPN05, OPP12, OPQ18, OPR20, OPT07 and OPV09). Primers were purchased in commercially available kits from OPERON Technologies (Alameda, USA). Amplified products were electrophoresed on $1 \%$ agarose, $1 \%$ Nu-Sieve agarose, $1 \times$ TBE gels, and visualised by ethidium bromide staining. Bands were scored manually using the Kodak Digital Science 1D Software program.

Statistical analysis. Amplified fragments were scored for the presence (1) or absence (0) of homologous bands to create a binary matrix of the different RAPD phenotypes. Shannon's information index as a measure of RAPD band diversity within populations was calculated as $H_{0}=-\Sigma\left(p_{i}\right.$ $\left.\log _{2} p_{i}\right)$, where $p_{i}$ is the phenotypic frequency.

The matrix of inter-individual Dice's distance coefficients (Dice, 1945; Nei and Li, 1979) was subjected to a principal co-ordinate analysis (PCoA). From the distance matrix, new independent axial co-ordinates, which represent most of the variability of the original data, were calculated using NTSYS-pc ver. 2.1 (Rohlf, 2000). The individuals were then plotted as points in a two-dimensional continuous space defined by the first two co-ordinates.

The Dice's distance matrix was analysed by the analysis of molecular variance (AMOVA) approach using WINAMOVA 1.55 program. Total genetic variation was partitioned according to subspecies/regions and populations. The significance of $\varphi$-statistics was obtained non-parametrically by 1000 permutations. Homogeneity of intra-group molecular variances (homoscedasticity) was tested using the HOMOVA procedure (modified Barlett's test), also carried out in WINAMOVA (Stewart and Excoffier, 1996). Modified Barlett's statistics null distributions were obtained after 1000 permutations. 
Table 1. Number of each population, region, number of herbarium catalogue, collection site, host and number of samples analyzed per population.

\begin{tabular}{|c|c|c|c|c|c|c|}
\hline No. & Species & Region & $\begin{array}{c}\text { No. } \\
\text { herbarium } \\
\text { COA }\end{array}$ & Site & Host & $\begin{array}{c}\text { No. } \\
\text { samples } \\
\text { collected. }\end{array}$ \\
\hline 1 & O. gracilis var. gracilis & $\mathrm{N}$ & 34043 & Teruel / Griegos & $\begin{array}{l}\text { Coronilla minima ssp. } \\
\text { minima }\end{array}$ & 9 \\
\hline 2 & O. gracilis var. gracilis & $\mathrm{N}$ & 34044 & Teruel / Royuela & Genista scorpius & 6 \\
\hline 3 & O. gracilis var. gracilis & $\mathrm{N}$ & 33922 & Huesca / Sin - Cruz de Guarda & Trifolium pratense & 6 \\
\hline 4 & O. gracilis var. gracilis & $\mathrm{N}$ & - & Vizcaya / Acantilados Barrika & Genista sp. & 9 \\
\hline 5 & O. gracilis var. gracilis & $\mathrm{N}$ & - & Vizcaya / Acantilados Gorliz & Genista $s p$ & 5 \\
\hline 6 & O. gracilis var. gracilis & S & 33924 & Cádiz / Pinar Público la Barrosa & Genista tridens & 10 \\
\hline 7 & O. gracilis var. gracilis & $S$ & 33923 & Córdoba / Pantano la Breña & Retama sphaerocarpa & 10 \\
\hline 8 & O. gracilis var. gracilis & $S$ & - & Córdoba / Medina Azahara & Retama sphaerocarpa & 9 \\
\hline 9 & O. gracilis var. gracilis & $S$ & - & Córdoba / Las Jaras & Retama sphaerocarpa & 10 \\
\hline 10 & O. gracilis var. gracilis & $S$ & 29916 & Córdoba / Fuente La Lancha & Retama sphaerocarpa & 10 \\
\hline 11 & O. gracilis var. gracilis & $S$ & 33925 & Córdoba / El Vacar-Obejo & Retama sphaerocarpa & 11 \\
\hline 12 & O. gracilis var. gracilis & $S$ & 33927 & $\begin{array}{l}\text { Córdoba / Obejo -Embalse } \\
\text { Guadalmellato }\end{array}$ & Retama sphaerocarpa & 10 \\
\hline 13 & O. gracilis var. gracilis & $S$ & 33921 & Córdoba / Las Ermitas & Retama sphaerocarpa & 6 \\
\hline 14 & $\begin{array}{l}\text { O. gracilis var. } \\
\text { deludens }\end{array}$ & $S$ & 33912 & Cádiz / Ctra. Ubrique-Cortes & Ulex baeticus & 5 \\
\hline 15 & $\begin{array}{l}\text { O. gracilis var. } \\
\text { deludens }\end{array}$ & $S$ & 33910 & Almería / Rodalquilar & Ulex parviflorus & 10 \\
\hline 16 & $\begin{array}{l}\text { O. gracilis var. } \\
\text { deludens }\end{array}$ & $S$ & 33920 & Cádiz / Villaluenga- Barrida & Ulex parviflorus & 11 \\
\hline 17 & $\begin{array}{l}\text { O. gracilis var. } \\
\text { deludens }\end{array}$ & $S$ & 33919 & Cádiz / Huerta Benamahoma & Ulex parviflorus & 10 \\
\hline 18 & $\begin{array}{l}\text { O. gracilis var. } \\
\text { deludens }\end{array}$ & $S$ & 33919 & Cádiz / Grazalema - Ronda & Ulex parviflorus & 10 \\
\hline 19 & $\begin{array}{l}\text { O. gracilis var. } \\
\text { deludens }\end{array}$ & $S$ & 33915 & Jaén / Cerro Mágina & Ulex parviflorus & 9 \\
\hline
\end{tabular}

\section{RESULTS}

RAPD analysis proved to be an efficient method for obtaining information on the population genetic of $O$. gracilis. The 15 RAPD primers generated a total of 123 reliable fragments in the 19 analysed populations, after excluding bands that were monomorphic for the whole data

set. Reliability was assessed by the maintenance of each polymorphic band in the total number of gels analysed. The number of bands per primer varied from 6 (OPI19 and 
Genetic diversity in two variants of Orobanche gracilis Sm.

Table 2. Phenotypic diversity revealed by 123 RAPD bands in 19 O. gracilis populations collected in different part of Spain.

\begin{tabular}{|c|c|c|c|c|c|c|c|}
\hline pop. & species & region & $\mathbf{n}$ & $n^{\circ}$ polym. loci & $\%$ polym. loci & $\mathbf{i}$ & sd (i) \\
\hline 1 & O. gracilis var. gracilis & $\mathrm{N}$ & 8 & 50 & 40.65 & 0.2323 & 0.2904 \\
\hline 2 & O. gracilis var. gracilis & $\mathrm{N}$ & 6 & 42 & 34.15 & 0.2026 & 0.2877 \\
\hline 3 & O. gracilis var. gracilis & $\mathrm{N}$ & 6 & 66 & 53.66 & 0.3074 & 0.2961 \\
\hline 4 & O. gracilis var. gracilis & $\mathrm{N}$ & 8 & 61 & 49.59 & 0.2815 & 0.2981 \\
\hline 5 & O. gracilis var. gracilis & $\mathrm{N}$ & 5 & 63 & 51.22 & 0.3026 & 0.3029 \\
\hline 6 & O. gracilis var. gracilis & $S$ & 8 & 45 & 36.59 & 0.2127 & 0.2881 \\
\hline 7 & O. gracilis var. gracilis & $S$ & 10 & 61 & 49.59 & 0.2846 & 0.3018 \\
\hline 8 & O. gracilis var. gracilis & $S$ & 9 & 50 & 40.65 & 0.2193 & 0.2797 \\
\hline 9 & O. gracilis var. gracilis & $S$ & 10 & 54 & 43.90 & 0.2586 & 0.3033 \\
\hline 10 & O. gracilis var. gracilis & $S$ & 10 & 43 & 34.96 & 0.1949 & 0.2812 \\
\hline 11 & O. gracilis var. gracilis & $S$ & 11 & 83 & 67.48 & 0.3380 & 0.2674 \\
\hline 12 & O. gracilis var. gracilis & $S$ & 10 & 61 & 49.59 & 0.2479 & 0.2652 \\
\hline 13 & O. gracilis var. gracilis & S & 6 & 38 & 30.89 & 0.1683 & 0.2588 \\
\hline 14 & O. gracilis var. deludens & $S$ & 11 & 59 & 47.97 & 0.2563 & 0.2855 \\
\hline 15 & O. gracilis var. deludens & $S$ & 10 & 40 & 32.52 & 0.1738 & 0.2652 \\
\hline 16 & O. gracilis var. deludens & $S$ & 11 & 41 & 33.33 & 0.1731 & 0.2569 \\
\hline 17 & O. gracilis var. deludens & $S$ & 8 & 39 & 31.71 & 0.1707 & 0.2608 \\
\hline 18 & O. gracilis var. deludens & $S$ & 10 & 44 & 35.77 & 0.1847 & 0.2622 \\
\hline \multirow[t]{4}{*}{19} & O. gracilis var. deludens & $S$ & 9 & 57 & 46.34 & 0.2428 & 0.2800 \\
\hline & Average & & 8.74 & 52.47 & 42.66 & 0.2343 & \\
\hline & Min. & & 5 & 38 & 30.89 & 0.1683 & \\
\hline & Max. & & 11 & 83 & 67.48 & 0.3380 & \\
\hline
\end{tabular}

$\mathrm{n}$ : number of samples per population.

I: Shannon's index.

sd: standard deviation.

OPJ01) to 15 (OPB03 and OPB15) with an average of 8.2 bands per primer. The size of the fragments ranged between 2083 and $275 \mathrm{bp}$. The proportion of polymorphic loci varied among populations from $30.89 \%$ to $67.48 \%$. None of the populations considered showed unique bands. Two of the RAPD primers analysed in this study (OPB03 and OPV09) also amplified well with other Orobanche species such as $O$. crenata (Román et al. 2001) and O. foetida (Román et al. 2006) and could be considered in future broomrape studies on population biology. 
Table 3. Independent axial coordinates, with the corresponding eigen value, percentage of explained variation and cumulative value.

\begin{tabular}{|c|c|c|c|}
\hline PCoA & eigen value & percent of variation & cumulative value \\
\hline 1 & 6.26747712 & 21.2401 & 21.2401 \\
\hline 2 & 5.96033594 & 20.1992 & 41.4393 \\
\hline 3 & 2.23532385 & 7.5754 & 49.0147 \\
\hline 4 & 2.01495539 & 6.8286 & 55.8433 \\
\hline
\end{tabular}

The diversity analysis within populations using Shannon's information measure revealed the highest diversity values in populations 3, 5 (O. gracilis var. gracilis from the North) and 11 (O. gracilis var. gracilis from the South) with values of $0.30,0.30$ and 0.33 respectively. The lowest value was found in population 13 of var. gracilis from the South showing a Shannon index of 0.16 (Table 2). The highest proportion of polymorphic loci was found in the population $11(67.48 \%)$ whereas the lowest value was that of population 13 (30.89\%). Considering 3 groups attending to the taxonomical variety and the origin of the populations, the highest values of the Shannon index were found in var. gracilis populations from the North with a mean value of $\overline{\mathrm{I}}$ $=0,27$ decreasing to the value of $\overline{\mathrm{I}}=0,24$ in the case of var. gracilis in the South and $\overline{\mathrm{I}}=0,20$ in the populations of var. deludens from the South.

These results indicate a higher level of diversity in the populations from the North when compared to the South ones as well as a higher level of variation in the populations of the var. gracilis when compared to the var. deludens. Although the two groups of var. gracilis from the North and South showed a similar percentage of polymorphic loci $(45.8 \%$ and $44.2 \%)$, the Shannon indexes remained different ( 0.27 and 0.24$)$ since this value not only depends on the proportion of polymorphic loci but also on the distribution of allelic frequencies in the populations.

The estimated Dice distance coefficients varied from 0.0175 to 1 with an average value of 0.5697 . The average distances among samples were plotted in a two-dimensional space using PCoA analysis (Figure 1). The general grouping clearly established the separation of samples according to the taxonomical variety and the geographical origin of each population. In this sense, the first PC1 that explained $21.24 \%$ of the total variation, clearly divided the three groups of individuals according to the botanical classification (var. gracilis from the $\mathrm{N}$ and $\mathrm{S}$ against var. deludens) (Table 3). In the case of PC2 explaining 20.19\% of the total variation, this axial coordinate separated the populations by their geographical origin, clearly distinguishing populations from the North and South of Spain. The cumulative value of the two coordinates was $41.44 \%$, being $7.57 \%$ and $6.82 \%$ the explained percentages of variation of the third and fourth ones.

The partition of variation in each group was studied with the analysis of the Dice's distance matrix by the AMOVA approach and a hierarchical analysis of phenotypic diversity using a two-way nested AMOVA was performed. In order

Table 4. AMOVA and homogeneity of molecular variance analysis for the partitioning of RAPD variation among groups and among populations within groups.

\begin{tabular}{|l|c|c|c|c|c|c|c|}
\hline Source of variation & df & Variance components \% Total variance $\varphi$-statistics & $\mathbf{p}(\varphi)^{\mathbf{a}}$ & Bartlett's index $^{\mathbf{p}(B)^{\mathbf{b}}}$ \\
\hline Among groups & 2 & 0.087 & 27.23 & 0.272 & $<0.001$ & 16.982 & $<0.001$ \\
\hline $\begin{array}{l}\text { Among populations / } \\
\text { Within groups }\end{array}$ & 16 & 0.084 & 26.26 & 0.361 & $<0.001$ & 6.094 & $<0.001$ \\
\hline Within populations & 147 & 0.149 & 46.52 & 0.535 & $<0.001$ & & \\
\hline
\end{tabular}

${ }^{a} p(\varphi): \varphi$-statistics probability level after 1000 permutations.

${ }^{b} p(B)$ : Bartlett's index probability level after 1000 permutatons. 
to clarify the different hierarchical ranges, we distributed the populations in three different groups: $O$. gracilis var. gracilis from the North, $O$. gracilis var. gracilis from the South and $O$. gracilis var. deludens from the South. We first determined the general variation among the groups and populations and then analysed the partition of the total variation among the three groups considered. Moreover, the pairwise group partitions were also determined in order to verify the PCoA analysis.

The general AMOVA (Table 4) revealed that although most of the genetic diversity was attributable to differences among individuals within populations $(46.52 \%)$, there was still a considerable level of variation among groups $(27.23 \%)$ and populations within groups $(26.26 \%)$ that showed significant associated $\varphi_{\text {st }}$ values. The HOMOVA analysis also indicated that the molecular variances were heterogeneous among groups and populations within groups, suggesting clear differences among them.

The AMOVA analysis was also performed in each one of the three groups considered in order to determine the genetic structure of their populations (Table 5). In this sense, the analysis showed that in the populations from the North, the higher level of variation is found within population $(80.09 \%)$ whereas only a $19.91 \%$ of the variation could be attributed to variation among populations. Both taxonomical varieties from the South (var. gracilis and var. deludens) presented a higher percentage of variation distributed among populations within the group (38.39\% and $48.40 \%$ respectively) thus indicating a higher phenotypic structure. The higher level of variation shared among var. deludens populations, as well as the higher value of the associated $\varphi_{\mathrm{st}}$ statistic, shows a higher genetic differentiation among the populations of this taxonomical variant when compared to the other two groups. In all the cases considered, the values of the $\varphi_{\mathrm{st}}$ statistic and Barlett index were significant.

Apart from the two AMOVA analysis described above, a third one determining the proportion of variation between groups was performed (Figure 1). The most different groups were those that shared the higher proportion of the total variance $(29.10 \%)$ corresponding to var. gracilis_South and var. deludens_South, where the percentage of variation shared between the two taxonomical variants from the North and the South was $27.95 \%$. Finally, the most similar groups were those with populations of $O$. gracilis var. gracilis from two distant regions of Spain $(25.45 \%)$. The $\varphi_{\text {st }}$ statistics and Barlett indexes were significant in the three analysis (data not shown).

\section{DISCUSSION}

Although this study shows that both taxonomical varieties can be distinguished according to the molecular genotyping, the partition of variation between groups belonging to different variants is only slightly higher (29.10\% and $27.95 \%$ ) when compared to the variation between groups belonging to the same taxonomical variety $(25.45 \%)$. In this sense, considering the similar proportion of variation explained by the two principal coordinates (21.24\% and $20.19 \%$ ), the separation of the three groups regarding the taxonomical variety or the geographic origin seems to be almost the same. The high proportion of variation within populations of $O$. gracilis var. gracilis in the North could be masking the differences between both taxonomical varieties.

Table 5. AMOVA and homogeneity of molecular variance analysis for the partitioning of RAPD variation among and within populations in each group considered: $O$. gracilis var. gracilis $(\mathrm{N}), O$. gracilis var. gracilis $(\mathrm{S})$ and $O$. gracilis var. deludens (S).

\begin{tabular}{|c|c|c|c|}
\hline & $\begin{array}{c}\text { O. gracilis var. } \\
\text { gracilis N }\end{array}$ & $\begin{array}{c}\text { O. gracilis var. } \\
\text { gracilis S }\end{array}$ & $\begin{array}{c}\text { O. gracilis var. } \\
\text { deludens S }\end{array}$ \\
\hline No. of populations & 5 & 8 & 6 \\
\hline Total no. of individuals & 33 & 74 & 59 \\
\hline$\%$ variance among populations & 19.91 & 38.39 & 48.40 \\
\hline$\%$ variance within populations & 80.09 & 61.61 & 51.60 \\
\hline$\varphi_{\text {st }}$ & $0.199^{* * *}$ & $0.384^{* * *}$ & $0.484^{* * *}$ \\
\hline$B$ & $0.210^{* * *}$ & $2.574^{* * *}$ & $1.617^{* * *}$ \\
\hline
\end{tabular}

*** significant at $p<0.001$.

B: Bartlett's index. 
These results detected a lower level of intrapopulation diversity in both varieties from the South (var. gracilis and var. deludens) contrasting with the high intrapopulation variability found in var. gracilis in the North of Spain with $19.91 \%$ of variation shared among populations. In other $O$. species, the proportion of variability reported among populations presented a wide range of variation: $47 \%$ in $O$. cumana Wallr. (Gagne et al. 1998) or $0.09 \%$ and $11.76 \%$ among $O$. crenata Forsk. populations from Spain and Israel respectively (Román et al. 2002). In all these cases, the authors related the level of interpopulation variability with the mating system, since high values of genetic diversity within populations seems to be a common pattern in outcrossing plants, whereas selfing species would be more likely to reveal a contrasting pattern (Nybom and Bartish, 2000). As pointed out by Hamrick and Godt (1989), autogamous species promote differentiation among populations while in mixed mating or allogamous species the differences are less marked.

Although we do not have evidence of the mating system of O. gracilis, contrasting results seem to be obtained for both taxonomical varieties. In the case of var. gracilis from the North, the low level of differentiation among populations $(19.91 \%)$ is similar to that reported for other allogamous species of the genera such as $O$. crenata (Román et al. 2001; Román et al. 2002). Nevertheless, the same species in the South as well as the taxonomical var. deludens, present a relatively higher level of interpopulation differentiation (38.39\% and $48.40 \%$ respectively) more in agreement with the pattern of genetic variation in a selfing species such as O. cumana, or O. minor (Gagne et al. 1998, Westwood and Fagg, 2004). Although factors which affect effective seed dispersal could explain the high level of variation within populations of $O$. gracilis var. gracilis in the North, the gene flow by pollen might have a considerable impact on the genetic structure of these populations since seed dispersal distances are limited to the proximate surroundings of the mother plants.

The fact that the populations belonging to the same taxonomical variety showed lower levels of intrapopulation variability in the South when compared to the North, could be suggesting a founder effect, considering that in general populations have greatest genetic diversity in their native regions, with colonizing subpopulations showing less within population variation (Amsellen et al. 2000). High genetic variability could represent an advantage for a species adapting to a new environment, allowing the species to establish and survive, whereas a reduced genetic variation lowers the adaptability of a population increasing the risk of extinction in an event of changes in habitat conditions. While gene flow among populations increases the variation within and decreases the variation between populations, genetic drift acts reciprocally. Therefore we may speculate that the samples of $O$. gracilis var. gracilis from the South originated from the Northern ones where higher levels of variability have been found. After this event, differences among $O$. gracilis var. gracilis populations from both distant regions of Spain could be attributed to the spatial distance, since it provides a substantial barrier to gene exchange promoting the appearance of genetic differentiation among populations from both regions.

As far as we are concerned this is the first report dealing with the pattern of variation in $O$. population attacking wild species. In this case, the distribution of variability is only related to its ability to disperse their pollen and /or seeds since no human acts are supposed to be involved on its distribution through the movement of commercial seeds from one place to another. The distribution of variation in this type of populations should indicate more ancient events that those provided by parasites growing on crops.

In the future, the analysis of new $O$. gracilis populations covering new geographical regions and hosts, together with the development of more robust makers to study genetic diversity in $O$. populations such as codominant microsatellites markers, will led to better understand the evolution of parasitic plants of wild flora still not adapted to agroecosystems.

\section{REFERENCES}

AMSELLEN, L.; NOYER, J.L.; LE BOURGEOIS, T. and HOSSAERT-MCKEY, M. Comparison of genetic diversity of the invasive weed Rubus alceifolius Poir. (Rosaceae) in its native range and in areas of introduction, using amplified fragment length polymorphism (AFLP) markers. Molecular Ecology, April 2000, vol. 9, no. 4, p. 443-455.

DICE, Lee R. Measures of the amount of ecologic association between species. Ecology, July 1945, vol. 26, no. 3, p. 297-302.

GAGNE, G.; ROECKEL-DREVET, P.; GREZESBESSET, B.; SHINDROVA, P.; IVANOV, P.; GRANDRAVEL, C.; VEAR, F.; TOURVIEILLE DE LABROUHE, D.; CHARMET, G. and NICOLAS, P. Study of the variability and evolution of Orobanche cumana populations infesting sunflower in different European countries. Theoretical and Applied Genetics, June 1998, vol. 96, no. 8, p. 1216-1222.

HAMRICK, J.L. and GODT, M.J.W. Allozyme diversity in plant species. In: BROWN, Anthony H.D.; CLEGG, Michael T. and KAHLER, Alex eds. Plant population genetics, breeding and genetic resources. Sinauer Associates Inc, Sunderland, 1989, p. 43-63.

KHARRAT, M.; HALILA, M.H.; LINKE, K.H. and HADDAR, T. First report of Orobanche foetida Poiret on faba bean in Tunisia. FABIS Newsletter, 1992, vol. 30, p. 46-47.

NEI, M. and LI, W.H. Mathematical model for studying genetic variation in terms of restriction endonucleases. Proceedings of the National Academy of Sciences of the 
United States of America, October 1979, vol. 76, no. 10, p. 5269-5273.

NYBOM, Hilde and BARTISH, Igor V. Effects of life history traits and sampling strategies on genetic diversity estimates obtained with RAPD markers in plants. Perspectives in Plant Ecology, Evolution and Systematics, 2000, vol. 3, no. 2, p. 93-114.

PUJADAS-SALVÀ, A.J.O. In: LÓPEZ SÁEZ, J.A.; CATALÁN, P. and SÁEZ, Ll. eds. Plantas Parásitas de la Península Ibérica e Islas Baleares. Mundi Prensa, Madrid, 2002, p. 345-451.

PUJADAS-SALVÀ, Antonio J. and PLAZA ARREGUI, Laura. What is Orobanche haenseleri var. deludens Beck? Anales del Jardín Botánico de Madrid, 2004, vol. 61, no. 2, p. 129-134.

ROHLF, F.J. NTSYS-pc, Numerical Taxonomy and Multivariate Analysis System, Version 2.1. Exeter Publications, New York, USA, 2000.

ROMÁN, B.; RUBIALES, D.; TORRES, A.M.; CUBERO, J.I. and SATOVIC, Z. Genetic diversity in Orobanche crenata populations from Southern Spain. Theoretical and Applied Genetics, November 2001, vol. 103, no. 6-7, p. 1108-1114.

ROMÁN, B.; SATOVIC, Z.; RUBIALES, D.; TORRES, A.M.; CUBERO, J.I.; KATZIR, N. and JOEL, D.M. Variation among and within populations of the parasitic weed Orobanche crenata from Spain and Israel revealed by inter simple sequence repeat markers. Phytopathology, December 2002, vol. 92, no. 12, p. 1262-1266.

ROMÁN, B.; SATOVIC, Z.; ALFARO, C.; MORENO, M.T.; KHARRAT, M.; PÉREZ-DE-LUQUE, A. and RUBIALES, D. Host differentiation in Orobanche foetida Poir. Flora, 2006, vol. 202, no. 3. (In press).

RUBIALES, D.; SADIKI, M. and ROMÁN, B. First report of Orobanche foetida on common vetch (Vicia sativa) in Morocco. Plant Disease, 2005, vol. 89, p. 528.

STEWART, C.N. and EXCOFFIER, L. Assessing population structure and variability with RAPD data: Application to Vaccinium macrocarpon (American cranberry). Journal of Evolutionary Biology, 1996, vol. 9, no. 2 , p. $153-171$.

WESTWOOD, J.H. and FAGG, C.M. ISSR characterization of Orobanche minor populations in the U.S. In: Proceedings of the 8th International Parasitic Weeds Symposium. (2004, Durban, South Africa: IPPS). Joel, D.M. ed., p. 15. 